$$
\begin{aligned}
& \text { 남부지방 조경수종의 탄소저감과 계량모델 }{ }^{\dagger} \\
& \text { - 동백나무, 배롱나무 및 가시나무를 대상으로 - } \\
& \text { 조현길 }^{*} \cdot \text { 길승호 }^{* *} \cdot \text { 박혜미 }^{* * *} \cdot \text { 김진영*** }
\end{aligned}
$$

"강원대학교 생태조경디자인학과 교수 · "강원대학교 생태조경디자인학과 조교수 ·"강원대학교 생태조경디자인학과 강사

\title{
Carbon Reduction by and Quantitative Models for Landscape Tree Species in Southern Region - For Camellia japonica, Lagerstroemia indica, and Quercus myrsinaefolia -
}

\author{
Jo, Hyun-Kil ${ }^{*}$ Kil, Sung-Ho ${ }^{* *} \cdot$ Park, Hye-Mi $^{* * *} \cdot \mathrm{Kim}$, Jin-Young $^{* * *}$ \\ "Professor, Dept. of Ecological Landscape Architecture Design, Kangwon National University \\ *Assistant Professor, Dept. of Ecological Landscape Architecture Design, Kangwon National University \\ ${ }^{*}$ Lecturer, Dept. of Ecological Landscape Architecture Design, Kangwon National University
}

\begin{abstract}
This study quantified, through a direct harvesting method, storage and annual uptake of carbon from open-grown trees for three landscape tree species frequently planted in the southern region of Korea, and developed quantitative models to easily estimate the carbon reduction by tree growth for each species. The tree species for the study included Camellia japonica, Lagerstroemia indica, and Quercus myrsinaefolia, for which no information on carbon storage and uptake was available. Ten tree individuals for each species (a total of 30 individuals) were sampled considering various stem diameter sizes at given intervals. The study measured biomass for each part of the sample trees to quantify the total carbon storage per tree. Annual carbon uptake per tree was computed by analyzing the radial growth rates of the stem samples at breast height or ground level. Quantitative models were developed using stem diameter as an independent variable to easily calculate storage and annual uptake of carbon per tree for study species. All the quantitative models showed high fitness with $r^{2}$ values of 0.94-0.98. The storage and annual uptake of carbon from a Q. myrsinaefolia tree with dbh of $10 \mathrm{~cm}$ were 24.0 $\mathrm{kg}$ and $4.5 \mathrm{~kg} / \mathrm{yr}$, respectively. A $C$. japonica tree and $L$. indica tree with $\mathrm{dg}$ of $10 \mathrm{~cm}$ stored $11.2 \mathrm{~kg}$ and $8.1 \mathrm{~kg}$ of carbon and annually sequestered $2.6 \mathrm{~kg}$ and $1.2 \mathrm{~kg}$, respectively. The above-mentioned carbon storage equaled the amount of carbon emitted from the gasoline consumption of about $42 \mathrm{~L}$ for Q. myrsinaefolia, $20 \mathrm{~L}$ for $C$. japonica, and $14 \mathrm{~L}$ for $L$. indica. A tree with the diameter size of $10 \mathrm{~cm}$ annually offset carbon emissions from gasoline use of approximately $8 \mathrm{~L}$ for $Q$. myrsinaefolia, $5 \mathrm{~L}$ for $C$. japonica, and $2 \mathrm{~L}$ for $L$. indica. The study pioneers in quantifying biomass and carbon reduction for the landscape tree species in the southern region despite difficulties in direct cutting and root digging of the planted trees.
\end{abstract}

Key Words: Carbon Offset, Open-grown Trees, Direct Harvesting, Tree Size, Biomass Measurement

\footnotetext{
${ }^{+}$: 본 연구는 산림청(한국임업진흥원) 산림과학기술 연구개발사업‘(2017043B10-1919-BB01)’의 지원에 의하여 이루어진 것임. Corresponding author: Hye-Mi Park, Lecturer, Dept. of Ecological Landscape Architecture Design, Kangwon National University, Chuncheon 24341, Korea, Tel.: +82-33-250-8345, E-mail: bhm63@kangwon.ac.kr
} 


\section{국문초록}

본 연구는 남부지방에 흔히 식재하는 3 개 조경수종을 대상으로 직접수확법을 통해 개방 생장하는 개체별 탄소저장 및 흡수를 계량화하고, 수종별 생장에 따른 탄소저감을 용이하게 산정하는 계량모델을 개발하였다. 연구 수종은 탄소저감 정보가 부재하는 동백나무, 배롱나무, 가시나무 등이었다. 유목에서 성목에 이르는 일정 간격의 줄기직경 규격을 고려하여 수종별로 10 개체씩, 총 30 개체의 수목을 구입하였다. 그리고 근굴취를 포함하는 직접 벌목을 통해 해당 개체의 부위별 및 전체 생체량을 실측하고, 탄소저장량을 산정하였다. 수종별 훙고직경 내지 근원직경의 줄기 원판을 채취하여 직경 생장률을 분석하고, 연간 탄소흡수량을 산출하였다. 줄기직경을 독립변수로 생장에 따른 수종별 단목의 탄소저장과 연간 탄소흡수를 산정하는 활용 용이한 계량모델을 도출하였다. 이들 계량모델의 $r^{2}$ 은 0.94 0.98로서 적합도가 높았다. 흥고직경 $10 \mathrm{~cm}$ 인 가시나무 단목의 탄소저장량과 연간 탄소흡수량은 각각 $24.0 \mathrm{~kg} /$ 주 및 $4.5 \mathrm{~kg} /$ 주 $/$ 년이었다. 근원직경 $10 \mathrm{~cm}$ 인 동백나 무와 배롱나무의 경우는 각각 $11.2 \mathrm{~kg}$ /주 및 $2.6 \mathrm{~kg} /$ 주 $/$ 년, $8.1 \mathrm{~kg}$ /주 및 $1.2 \mathrm{~kg} /$ 주/년이었다. 이 탄소저장량은 가시나무 약 $42 \mathrm{~L}$, 동백나무 $20 \mathrm{~L}$, 배롱나무 $14 \mathrm{~L}$ 의 휘발유 소비에 따른 탄소 배출량에 상당하였다. 또한, 상기한 직경의 가시나무, 동백나무 및 배롱나무 한 그루는 매년 각각 $8 \mathrm{~L}, 5 \mathrm{~L}, 2 \mathrm{~L}$ 의 휘발유 소비에 따른 탄소 배출량을 상쇄하는 역할을 담당하였다. 본 연구는 식재 수목의 직접 벌목과 근굴취의 난이성을 극복하고, 남부지방 대상 조경수종의 생체량 및 탄소저감을 계량화하 는 새로운 초석을 마련하였다.

주제어: 탄소상쇄, 개방생장 수목, 직접수확, 수목규격, 생체량 측정

\section{I. 서론}

주민 생활공간에 식재된 조경수목은 미세먼지를 포함한 대 기정화, 열섬현상 완화, 우수차집, 야생동물 유치 등에 기여할 뿐만 아니라, 광합성을 통한 생장과정에서 대기탄소를 흡수 및 저장하는 주요한 탄소흡수원이다. 따라서 국제적 환경 관심사 인 기후변화에 대응하기 위한 효과적 수단으로서 도시 조경수 목의 식재에 대한 관심이 증가하고 있는 상황이다. 탄소배출 감축 관련 UN 협약인 2005 교토의정서와 국가 온실가스 인벤 토리 작성 관련 $2006 \mathrm{IPCC}$ (Intergovernmental Panel on Climate Change) 가이드라인에 따르면 정주공간(settlement)의 $500 \mathrm{~m}^{2}$ 이상 식생복구(revegetation)는 탄소흡수원 증진활동으로서 인 정되며(UNFCCC, 2006; KFRI, 2012), 조경수목 식재는 직접 적으로 이 범주의 활동에 해당한다. 국내에서도 이러한 국제적 동향에 부응하기 위해 2010년에 저탄소 녹색성장 기본법을 제 정하여 녹지조성 및 보전 관련 탄소흡수원 확충을 제도화하였 다. 그리고 이 기본법에 따라 2012년에는 탄소흡수원 유지 및 증진에 관한 법률을 제정하여 신규조림 및 재조림과 함께 식생 복구를 탄소흡수원 확충 및 탄소상쇄 활동으로 명시하고 있다 (http://www.law.go.kr).

수목식재에 의한 일정 면적의 탄소흡수 및 저장 효과는 주로 생장률, 규격, 밀도 등에 따라 좌우된다. 따라서 그 효과의 파악 은 우선적으로 수종별 생장에 따른 단목 차원의 산정을 요구하 며, 해당 규격의 식재밀도를 반영하여 면적 차원으로 전환하는 과정을 수반한다. 과거 도시 조경수목의 탄소저장은 해당 산정 식이 부재하여 산림수목의 상대생장식을 대용하여 추정하는
간접적인 방법을 적용하였다(Jo et al., 1995; Jo, 2002; KFRI, 2010a; Park and Kang, 2010). 도시 조경수목은 경합 조건, 인 위적 관리 등 생장환경이 산림수목의 경우와 상이하므로, 산림 수목의 상대생장식 대용은 적지 않은 오차를 야기한다(Jo and Park, 2017). 이 한계성을 해소하기 위해 Jo and Cho(1998) 및 Jo and $\mathrm{Ahn}$ (2001)은 적외선가스분석기에 의한 연간 $\mathrm{CO}_{2}$ 교환 율의 측정을 통해 도시 조경수목의 탄소흡수를 계량화하였다. 다만, $\mathrm{CO}_{2}$ 교환율 측정법은 단위엽면적당 $\mathrm{CO}_{2}$ 교환율과 관련 환경인자, 비동화기관 호흡량, 직경크기에 따른 엽면적 등 다양 한 변수들의 지속적인 측정과 복잡한 산정과정에서 발생하는 추정 오차가 상당할 수 있다. 탄소흡수 및 저장의 산정 오차를 줄일 수 있는 가장 바람직한 방법은 벌목과 근굴취를 포함하 는 직접수확법이다. 최근, 중부지방에서 식재빈도가 높은 다수 의 낙엽 및 상록 조경수종을 대상으로 직접수확법을 적용하여 수종별 생장에 따른 탄소흡수 및 저장을 계량화한 바 있다(Jo and Ahn, 2012; Jo et al., 2013; 2014; Jo and Park, 2017).

국외에서는 오래 기간 도시 조경수목의 탄소저감 관련 다양 한 연구정보를 구축하고(Nowak, 1994; Jo and McPherson, 1995; McPherson, 1998; Nowak and Crane, 2002; Nowak et al., 2013; McGovern and Pasher, 2016), 아울러 도시녹지의 탄 소저감을 용이하게 평가하는 컴퓨터 프로그램을 개발하여(http: //www.itreetools.org) 저탄소 도시의 조성지침 및 정책수립에 활용하고 있다. 국내의 경우, 1990 년대 중반부터 도시녹지의 탄 소저감 연구를 수행하기 시작하였으나(Jo et al., 1995), 아직 도시 및 지역별 해당 연구정보가 제한적이다. 특히 난온대 기 후권에서 생장하는 수종별 도시 조경수목의 탄소흡수 및 저장 
을 계량화한 연구는 부재하는 실정이다. 따라서 본 연구의 목 적은 남부지방에 흔히 식재하는 일부 조경수종을 대상으로 직 접수확법을 통해 개체별 탄소저장 및 흡수를 계량화하고, 수종 별 생장에 따른 탄소저감을 용이하게 산정하는 계량모델을 개 발하는 것이다. 본 연구는 남부지방 도시의 식재수목에 의한 탄소흡수원 역할을 구명하는데 유용할 것으로 기대한다. 본 논 문에서 탄소저장은 수목이 생장하면서 여러 해 동안 축적한 총 량을, 탄소흡수는 수목이 한 해 동안 흡수한 양을 의미한다.

\section{II. 연구내용 및 방법}

\section{1. 수목굴취 및 생체량 측정}

\section{1) 굴취 수종 및 수목 선정}

국내 도시의 조경수종 식재현황 관련 선행연구(KFS, 2014; $\mathrm{DMC}, 2017)$ 를 검토하여 난온대 및 온대남부 기후권의 남부지 방에 흔히 식재하는 조경수종 중 탄소저감 연구가 부재하는 동 백나무(Camellia japonica), 배롱나무(Lagerstroemia indica), 가 시나무(Quercus myrsinaefolia) 등 3개 교목종을 연구수종으로 선정하였다. 남부지방의 식재공간과 조경수 재배농장을 현장 실사하여 연구목표 달성에 부합하는 개방 생장한 수목을 수종 별로 각각 10 개체씩, 총 30 개체를 구입하였다. 즉, 수종별로 유 목에서 성목에 이르는 일정 간격의 직경 크기를 고려하고, 수 종 특유의 수형을 유지하면서 수관 등이 정상 생장한 개체를 굴취수목으로 선정하였다. 굴취수목 개체수의 결정은 수목 구 입이나 측정과정에 필요한 비용 및 시간과 표본수의 충분한 확 보라는 대립적 양면을 가감 조정한 것이다.

\section{2) 현장굴취 및 생중량 측정}

구입 수목은 수종에 따라 10 월 중순 하순에 걸쳐 현장에서 직접 굴취하여 줄기, 가지, 잎, 뿌리로 분류한 부위별 생중량을 측정하였다(Figure 1 참조). 현장굴취와 생중량 측정은 $\mathrm{KFRI}$ (2007) 및 Jo et al.(2014)의 바이오매스 조사·분석 표준방법 을 적용하였다. 굴취 시 Jo et al.(2014)의 방법과 같이 줄기직 경, 수관폭, 수고 등 각 개체의 크기를 측정하였다. 그리고 수종 별 3개소씩 생장공간의 토양표본을 채취하여 $\operatorname{KIAST}(2000)$ 의 토양분석 표준방법을 토대로 생장기반의 물리화학적 특성을 파악하였다.

\section{3) 건중량 표본채취 및 측정}

생중량 대비 건중량(이하 생체량으로 지칭)을 산출하기 위 해 부위별 생체량 환산용 표본을 채취하고, 현장에서 $10 \mathrm{~g}$ 단위 까지 생중량을 실측하였다. 즉, 가시나무의 줄기는 $2 \mathrm{~m}$ 간격으 로, 수고 $2.5 \mathrm{~m}$ 미만의 소형 수목표본을 포함하는 배롱나무와

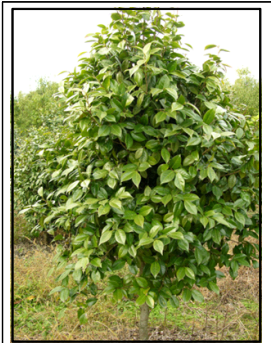

a: Camellia japonica

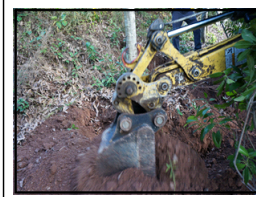

d: Digging roots

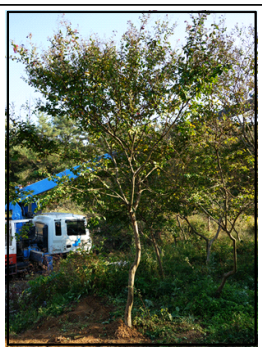

b: Lagerstroemia indica

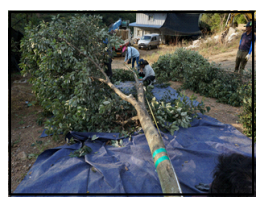

e: Separating branches

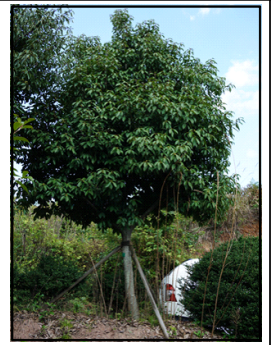

: Quercus myrsinaefolia

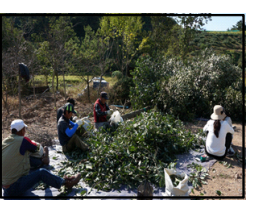

f: Separating leaves
Figure 1. Growing conditions and harvesting of study trees

동백나무의 줄기는 $1 \mathrm{~m}$ 간격으로 두께 $5 \sim 10 \mathrm{~cm}$ 의 원판을 채취 하였다. 가지는 해당 수목의 굵은 가지, 중간 가지 및 가는 가 지를 골고루 섞어 1 3kg을, 뿌리는 그루터기와 타 부위로 분 류하여 각각 1 3kg을, 그리고 잎은 $0.5 \sim 1 \mathrm{~kg}$ 을 채취하였다. 생 체량 환산용 표본은 $85^{\circ} \mathrm{C}$ 건조기에서 항량이 될 때까지 건조시 킨 뒤, 전자저울로 $0.01 \mathrm{~g}$ 단위까지 그 무게를 측정하였다. 그리 고, 부위별 표본의 생중량 대비 생체량의 비를 산정하고, 이를 해당 개체의 생중량에 적용하여 단목의 부위별 및 전체 생체량 을 산출하였다.

\section{2. 탄소저장 계량모델 개발}

연구대상 수목의 생체량 측정결과를 토대로 수종별 생장에 따른 단목의 탄소저장을 용이하게 추정하는 계량모델을 유도 하였다. 즉, 수목의 목질부 및 잎의 평균 탄소함량은 생체량의 약 50\%이므로(Pingrey, 1976; Chow and Rolfe, 1989; Song et al., 1997; Jo, 2002; Nowak and Crane, 2002), 생체량에 0.5를 곱하여 탄소저장량으로 전환하였다. 그리고 흥고 또는 근원직 경, 수고, 수관폭을 독립변수로 반복적인 선형 및 비선형 접근 을 추진하여, 각 수종의 탄소저장량을 산출하는 가장 적합한 회귀식과 변수를 최종적으로 도출하였다.

\section{3. 탄소흡수 계량모델 개발}

가시나무는 지상 $1.2 \mathrm{~m}$ 의 흥고부위에서, 동백나무와 배롱나 무는 근원부에서 두께 $5 \sim 10 \mathrm{~cm}$ 의 줄기 원판을 채취하고, 바로 이중 비닐백에 넣어 연구실로 운반한 뒤 수종별 수령과 연간 직경생장률을 파악하였다. 원판 두께는 KFRI(2007)의 표준에 따르되 취급 시 파손 방지, 그라인딩 작업의 효율성 등을 고려 하여 줄기 굵기에 따라 결정하였다. 직경생장률은 각 원판의 4 
개 직각방향에서 측정한 생장률을 평균하여 산출하였다. 직경 생장 분석결과를 바탕으로 연간 증가된 생체량을 구한 후 탄 소함량비 0.5 를 곱하여 각 개체의 탄소흡수량을 산정하였다. 즉, 연간 직경생장률을 이용하여 구한 전년도의 직경을 생체 량 산정식에 대입하여 전년도의 생체량을 산출하고, 이를 현년 도의 생체량에서 제감하여 생체량의 연간 증가량을 산정하였 다(Nowak, 1994; Jo, 2002). 배롱나무 잎은 대개 낙엽과 분해를 통해 해마다 흡수한 탄소를 대기에 환원하므로 한 해 동안 증 가된 생체량에서 제감하였다. 한편, 상록수인 가시나무와 동백나 무의 경우는 3년간의 잎 수명을 가정하여(Dirr, 2009; Rowntree and Nowak, 1991) 25\% 엽량을 제감하였다. 그리고 흉고 또는 근원직경, 수고, 수관폭을 독립변수로 반복적인 선형 및 비선형 접근을 추진하여 수종별 생장에 따른 단목의 탄소흡수를 용이 하게 추정하는 가장 적합한 계량모델을 도출하였다.

\section{III. 결과 및 고찰}

\section{1. 수목 생장기반 및 생체량}

연구대상 굴취수목은 동백나무의 경우 강진군, 배롱나무는 진주시와 하동군, 가시나무는 진주시 등의 정원, 가로, 조경수 농장에 식재된 것이었다(Table 1 참조). 가시나무의 흉고직경 은 수목에 따라 3.1 16.6cm이었고, 동백나무와 배롱나무의 근 원직경은 각각 $3.5 \sim 9.9 \mathrm{~cm}, 2.8 \sim 13.7 \mathrm{~cm}$ 의 범위이었다. 이들 수 목의 수령은 줄기 원판의 연륜분석 결과, 최소 5 최대 20년생 이었다. 가시나무의 연간 흉고직경 생장률은 $0.83 \mathrm{~cm} /$ 년이었으
며, 동백나무와 배롱나무의 연간 근원직경 생장률은 $0.65 \mathrm{~cm} /$ 년 및 $0.73 \mathrm{~cm} /$ 년이었다. 수목의 연간 생장률은 생체량 및 탄소흡 수량의 다소를 좌우한다. 국내 중부지방에 식재된 여러 도시 조경수종의 수령 30 년에 걸친 연간 흉고직경 생장률은 낙엽활 엽수 평균 $0.72 \mathrm{~cm} /$ 년 및 상록침엽수 $0.83 \mathrm{~cm} /$ 년이었고, 상록침 엽수종 대상 산림수목의 경우는 $0.57 \mathrm{~cm} /$ 년이었다(Jo and Park, 2017). 본 연구대상 가시나무의 흉고직경 생장률은 상기한 도 시 상록침엽수의 경우와 유사하였고, 산림수목보다는 약 1.5 배 컸다. Jo et al.(2014)에 따르면 산수유(Cornus officinalis) 와 주 목( Taxus cuspidata)의 연간 근원직경 생장률은 각각 $0.75 \mathrm{~cm} /$ 년 및 $0.40 \mathrm{~cm} /$ 년으로서, 본 동백나무와 배롱나무의 경우는 산 수유보다 다소 작았으나, 주목보다는 훨씬 큰 것으로 나타났다.

연구대상 수목 토양의 물리화학적 특성은 Table 2와 같으며, 토성은 수종에 따라 양토 또는 사질식양토이었다. 화학성은 $\mathrm{pH}$ $5.0 \sim 6.0$, 유기물 0.3 2.1\%, 전질소 $0.05 \sim 0.20 \%$, 유효인산 47.6 $376.6 \mathrm{mg} / \mathrm{kg}$, 양이온치환능 $1.9 \sim 9.0 \mathrm{cmol}^{+} / \mathrm{kg}$ 등이었다. KILA (2016)의 조경설계기준에 수록된 토양의 항목별 평가등급에 준 하면 동백나무의 생장 토양은 분석항목 전체에 걸쳐 하급에 해 당하였고, 배롱나무의 경우 $\mathrm{pH}$ 와 유기물을 제외한 타 항목이 중급 이상이었다.

단목(單木)의 총 생체량은 직경에 따라 동백나무 1 16kg/주, 배롱나무 1 35kg/주, 가시나무 2 161kg/주 등이었다(Figure 2 참조). 수목 부위별 생체량의 평균 점유비는 수종에 따라 차이 를 보였으며, 가시나무의 경우 줄기가 $33 \%$ 로서 가장 높았고, 이 어서 뿌리와 가지 각각 $28 \%$ 및 $27 \%$, 잎 $12 \%$ 등의 순이었다. 소 교목성인 배롱나무는 가지 점유비가 가장 높은 $36 \%$ 이었고(줄

Table 1. Size and diameter growth of study trees by species

\begin{tabular}{c|c|c|c|c|c|c}
\hline Species & Growth place & Diameter $^{*}(\mathrm{~cm})$ & Crown width $(\mathrm{m})$ & Height $(\mathrm{m})$ & Age $(\mathrm{yr})$ & Diameter growth $(\mathrm{cm} / \mathrm{yr})$ \\
\hline Camellia japonica & Garden \& nursery (Gangjin) & $3.5 \sim 9.9$ & $0.5 \sim 1.5$ & $1.5 \sim 3.5$ & $7 \sim 12$ & $0.65 \pm 0.06$ \\
\hline Lagerstroemia indica & Nursery (Jinju \& Hadong) & $2.8 \sim 13.7$ & $0.9 \sim 4.3$ & $2.1 \sim 5.4$ & $6 \sim 20$ & $0.73 \pm 0.06$ \\
\hline Quercus myrsinaefolia & Garden, street \& nursery (Jinju) & $3.1 \sim 16.6$ & $1.2 \sim 4.6$ & $3.7 \sim 7.9$ & $5 \sim 16$ & $0.83 \pm 0.06$ \\
\hline
\end{tabular}

It indicates stem diameter at breast height of $1.2 \mathrm{~m}$ (dbh) for Q. myrsinaefolia and stem diameter at ground level (dg) for $C$. japonica and $L$. indica (the same with subsequent tables and figures)

Table 2. Physical and chemical characteristics of growth soils for study species

\begin{tabular}{|c|c|c|c|c|c|c|c|c|c|}
\hline \multirow{2}{*}{ Species } & \multirow{2}{*}{ Soil texture } & \multirow{2}{*}{$\mathrm{pH}$} & \multirow{2}{*}{$\begin{array}{l}\mathrm{OM} \\
(\%)\end{array}$} & \multirow{2}{*}{$\begin{array}{l}\mathrm{TN} \\
(\%)\end{array}$} & \multirow{2}{*}{$\begin{array}{l}\text { Ava. P } \\
(\mathrm{mg} / \mathrm{kg})\end{array}$} & \multicolumn{3}{|c|}{$\mathrm{EC}\left(\mathrm{cmol}^{+} / \mathrm{kg}\right)$} & \multirow{2}{*}{$\begin{array}{c}\mathrm{CEC} \\
\left(\mathrm{cmol}^{+} / \mathrm{kg}\right)\end{array}$} \\
\hline & & & & & & $\mathrm{K}^{+}$ & $\mathrm{Ca}^{2+}$ & $\mathrm{Mg}^{2+}$ & \\
\hline Camellia japonica & Sandy clay loam & $\begin{array}{c}5.3 \\
\text { (low) }\end{array}$ & $\begin{array}{c}0.6 \\
\text { (low) }\end{array}$ & $\begin{array}{c}0.05 \\
\text { (low) }\end{array}$ & $\begin{array}{c}61.7 \\
\text { (low) }\end{array}$ & $\begin{array}{c}0.13 \\
\text { (low) }\end{array}$ & $\begin{array}{c}0.88 \\
\text { (low) }\end{array}$ & $\begin{array}{c}0.32 \\
\text { (low) }\end{array}$ & $\begin{array}{c}1.9 \\
\text { (low) }\end{array}$ \\
\hline Lagerstroemia indica & Loam & $\begin{array}{c}5.0 \\
\text { (low) }\end{array}$ & $\begin{array}{c}2.1 \\
\text { (low) }\end{array}$ & $\begin{array}{c}0.20 \\
\text { (high) }\end{array}$ & $\begin{array}{c}376.6 \\
\text { (high) }\end{array}$ & $\begin{array}{c}0.76 \\
\text { (middle) }\end{array}$ & $\begin{array}{c}4.10 \\
\text { (middle) }\end{array}$ & $\begin{array}{c}0.84 \\
\text { (middle) }\end{array}$ & $\begin{array}{c}6.3 \\
\text { (middle) }\end{array}$ \\
\hline Quercus myrsinaefolia & Loam & $\begin{array}{c}6.0 \\
\text { (middle) }\end{array}$ & $\begin{array}{c}0.3 \\
\text { (low) }\end{array}$ & $\begin{array}{c}0.09 \\
\text { (middle) }\end{array}$ & $\begin{array}{l}47.6 \\
\text { (low) }\end{array}$ & $\begin{array}{c}0.16 \\
\text { (low) }\end{array}$ & $\begin{array}{c}6.71 \\
\text { (high) }\end{array}$ & $\begin{array}{c}1.58 \\
\text { (middle) }\end{array}$ & $\begin{array}{c}9.0 \\
\text { (middle) }\end{array}$ \\
\hline
\end{tabular}

OM: Organic matter, TN: Total nitrogen, Ava. P: Available $\mathrm{P}_{2} \mathrm{O}_{5}$, EC: Exchangeable cation, CEC: Cation exchange capacity, ( ): Soil assessment rating based on KILA (2016)'s standards 
기 $30 \%$, 뿌리 $24 \%$, 잎 $10 \%$ ), 동백나무는 뿌리 $30 \%$, 잎 $25 \%$, 줄기 $24 \%$, 가지 $21 \%$ 등의 순으로서 특히 잎의 점유비가 타 수 종에 비해 높았다. 수종별 굴취수목의 생체량 확장계수(줄기 생체량 대비 줄기, 가지 및 잎을 합계한 비율)와 지하부/지상 부 비율은 Table 3 과 같다. 생체량 확장계수는 수종에 따라 평 균 2.18 3.77로서, 동백나무를 제외하면 국내 상록침엽 조경수 목의 1.91 2.86 범위(Jo et al., 2013; 2014)에 해당하였다. 동 백나무의 생체량 확장계수가 상대적으로 큰 이유는 전기한 바 와 같이 잎의 생체량 점유비가 높기 때문이다. 한편, 본 연구대 상 수종의 생체량 확장계수는 흉고직경이 최대 $40 \mathrm{~cm}$ 인 상록성 산림수목의 1.47 2.62(KFRI, 2010b; 2014)보다 높은데, 이는 수령 차이, 개방 생장에 따른 지엽밀도 차이, 관리에 따른 생장 환경 개선 등에 기인하는 것으로 판단된다. 수종별 지하부/지 상부 생체량비는 $0.27 \sim 0.44$ 로서, 중부지방에 식재된 여러 조경 수종의 경우인 0.22 0.49(Jo and Ahn, 2012; Jo et al., 2013; 2014)의 범위에 해당하였다. 이 생체량비는 식재 조경수의 근 굴취 난이성에 기인하여 미진했던 수종별 지상부 대비 지하부 의 생체량을 추정하는데 유용하다.

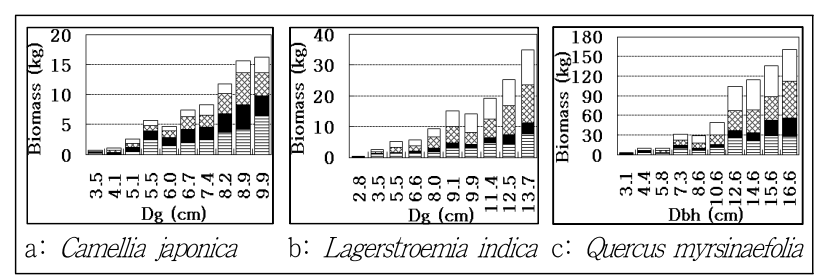

Figure 2. Changes in biomass by diameter growth of study trees for each species

Legend: $\square$ Stem $\otimes$ Branch $\square$ Leaf 目 Root

Table 3. Biomass expansion factor (BEF) and ratio of below ground/ above ground biomass $(B / A)$ for each species

\begin{tabular}{c|c|c}
\hline Species & $\mathrm{BEF}^{*}$ & $\mathrm{~B} / \mathrm{A}$ ratio \\
\hline Camellia japonica & $3.77 \pm 0.37$ & $0.44 \pm 0.05$ \\
\hline Lagerstroemia indica & $2.24 \pm 0.09$ & $0.27 \pm 0.02$ \\
\hline Quercus myrsinaefolia & $2.18 \pm 0.09$ & $0.34 \pm 0.04$ \\
\hline
\end{tabular}

Ratio of above ground (including stem, leaf and branch)/stem biomass

\section{2. 탄소저장과 계량모델}

연구대상 수목의 직경생장에 따른 탄소저장량은 Figure 3과 같고, Table 4는 최종 유도한 수종별 단목의 탄소저장량을 산 출하는 계량모델을 보여준다. 계량모델 모두는 $F$ 검정 결과 통 계적으로 유의하였고 $(p<0.0001), r^{2}$ 는 최소 0.94 이상으로 적합 도가 양호하였다. Y절편 및 직경의 회귀계수 역시 $t$ 검정 결과, $1 \%$ 수준에서 유의성을 나타냈다. 한편, 독립변수로서 줄기직 경 뿐만 아니라, 수고, 수관폭 등을 포함하는 계량모델을 도출
한 결과, 유의한 $F$ 값을 보였으나, 수고나 수관폭의 $r^{2}$ 가 훨씬 낮았다(0.82 이하). 수고를 포함하는 계량모델이 통계적으로 유의하더라도 현장조사 시 입목 상태의 정확한 수고 측정이 곤란하기 때문에 줄기직경 만을 이용한 경우보다 오히려 산정 오차가 클 수도 있다(Whittaker and Marks, 1975; Park and Lee, 1990). 본 연구에서 제시한 계량모델은 흉고 또는 근원직 경 만을 측정하여 수종별 단목 차원의 탄소저장량을 용이하게 산출하는데 활용할 수 있다.

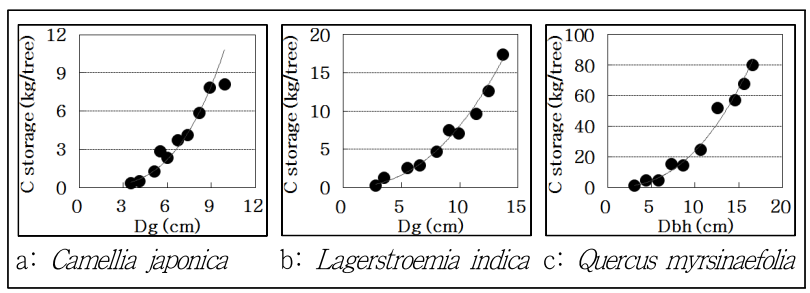

Figure 3. Changes in carbon storage per tree by diameter growth of study species

Table 4. Regression models to quantify carbon storage per tree of study species

\begin{tabular}{c|c|c|c}
\hline Species & Regression model & $t^{*}$ & $p$ \\
\hline Camellia japonica & $\ln \mathrm{Y}=-4.9154+3.1833 \ln D g$ & 0.9546 & $<0.0001$ \\
\hline Lagerstroemia indica & $\ln \mathrm{Y}=-3.2502+2.3199 \ln D g$ & 0.9439 & $<0.0001$ \\
\hline Quercus myrsinaefolia & $\ln \mathrm{Y}=-2.4849+2.4593 \ln \mathrm{lbh}$ & 0.9746 & $<0.0001$ \\
\hline${ }^{*} \mathrm{Y}:$ Carbon storage (kg/tree)
\end{tabular}

상기한 계량모델을 적용하여 수종 및 직경별 탄소저장량을 산정한 결과(Table 5 참조), 수목 1 주의 탄소저장량은 직경생 장과 더불어 증가하는 경향이었고, 직경급 간 그 차이는 직경 이 클수록 더욱 현저하였다. 즉, 직경이 $2 \mathrm{~cm}$ 커질 때마다 각 수 종의 탄소저장량은 최소 1.3 최대 3.7 배 증가하는 것으로 나타 났다. 수종별로는 흥고직경 $10 \mathrm{~cm}$ 기준 가시나무가 $24.0 \mathrm{~kg} /$ 주

Table 5. Comparison of carbon storage per tree by diameter growth for study species ( $\mathrm{kg} /$ tree)

\begin{tabular}{c|c|c|c|c|c|c|c|c|c}
\hline \multirow{2}{*}{ Method } & \multirow{2}{*}{ Species } & \multicolumn{7}{|c}{ Diameter $(\mathrm{cm})$} \\
\cline { 3 - 10 } & 4 & 6 & 8 & 10 & 12 & 14 & 16 & 18 \\
\hline \multirow{4}{*}{$\begin{array}{c}\text { Direct } \\
\text { harvestinga }\end{array}$} & \begin{tabular}{c} 
Camellia japonica \\
\cline { 2 - 10 }
\end{tabular} & 0.6 & 2.2 & 5.5 & 11.2 & 20.0 & - & - & - \\
\cline { 2 - 10 } & $\begin{array}{c}\text { indica } \\
\text { Quercus } \\
\text { myrsinaefolia }\end{array}$ & 2.5 & 6.8 & 13.9 & 24.0 & 37.6 & 54.9 & 76.2 & 101.8 \\
\hline \multirow{2}{*}{$\begin{array}{c}\text { Biomass } \\
\text { equationb }\end{array}$} & Quercus acuta & 4.9 & 11.1 & 19.9 & 31.6 & 46.5 & 64.9 & 86.9 & 113.0 \\
\cline { 2 - 10 } & Quercus glauca & 2.9 & 7.2 & 13.9 & 23.2 & 35.5 & 50.9 & 69.8 & 92.3 \\
\hline
\end{tabular}

a Applying Regression models from open-grown landscape trees of this study

${ }^{b}$ Applying biomass equations from southern forest-grown trees (KFRI, 2014) 
이고, 근원직경 $10 \mathrm{~cm}$ 의 동백나무와 배롱나무가 각각 $11.2 \mathrm{~kg}$ / 주 및 $8.1 \mathrm{~kg}$ /주이었다. 가시나무의 탄소저장량은 중부지방에 식 재된 여러 조경수종의 경우(Jo and Ahn, 2012; Jo et al., 2014) 와 비교하면, 동일 규격의 낙엽수종 평균치보다 약 1.3 배 $(19 \mathrm{~kg} /$ 주), 그리고 상록수종 평균치보다 2배 (12kg/주) 더 많았다. 한 편, 난대림 대표 수종인 붉가시나무(Quercus acuta) 와 종가시 나무(Quercus glauca) 산림수목의 탄소저장량은 동일 규격 기 준 각각 약 $32 \mathrm{~kg}$ /주 및 $23 \mathrm{~kg}$ /주로서 (KFRI, 2014), 본 가시나 무의 탄소저장량은 붉가시나무보다 적고, 종가시나무보다는 약 간 더 많았다. Jo et al.(2014)에 의하면, 근원직경 $10 \mathrm{~cm}$ 인 산수 유와 주목의 탄소저장량은 각각 $9.3 \mathrm{~kg}$ /주 및 $6.3 \mathrm{~kg}$ /주이었다. 동일 규격 기준 본 동백나무의 탄소저장량은 산수유보다 약 1.2 배, 주목보다 1.8 배 더 많았고, 본 배롱나무의 경우는 산수유 와 주목의 중간치에 해당하였다. 휘발유 $10 \mathrm{~L}$ 의 소비는 약 $5.7 \mathrm{~kg}$ 의 탄소를 대기에 배출하는데 (https://www.gir.go.kr), 흉고직경 $10 \mathrm{~cm}$ 인 가시나무 한 그루는 $42 \mathrm{~L}$ 의 휘발유 소비를, 그리고 근원직경 $10 \mathrm{~cm}$ 인 동백나무와 배롱나무는 14 20L의 휘발유 소비에 따라 배출되는 탄소량을 저장하고 있는 셈이다.

\section{3. 탄소흡수와 계량모델}

수종별 단목의 직경생장에 따른 탄소흡수량 변화와 탄소흡 수량을 산출하는 계량모델은 각각 Figure 4 및 Table 6과 같다. 계량모델 모두는 $F$ 검정 결과 통계적으로 유의하였고 $(p<0.0001)$, $r^{2}$ 은 최소 0.95 이상으로서 적합도가 양호하였다. Y절편 및 직 경의 회귀계수도 $t$ 검정 결과, $1 \%$ 수준에서 유의성을 나타냈다. 한편, 탄소저장량의 경우처럼 독립변수로서 줄기직경 외에도 수고, 수관폭 등을 고려하는 계량모델을 유도하였으나, $F$ 값이 유의하더라도 수고와 수관폭의 회귀계수가 $5 \%$ 수준에서 유의

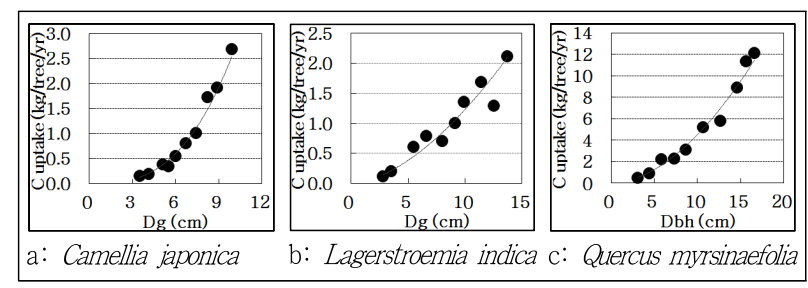

Figure 4. Changes in carbon uptake per tree by diameter growth of study species

Table 6. Regression models to quantify carbon uptake per tree of study species

\begin{tabular}{c|l|c|c}
\hline Species & Regression model & $r^{2}$ & $p$ \\
\hline Camellia japonica & $\ln \mathrm{Y}=-5.6582+2.8731 \ln D g$ & 0.9811 & $<0.0001$ \\
\hline Lagerstroemia indica & $\ln \mathrm{Y}=-3.2160+1.4838 \ln \mathrm{Dg}$ & 0.9517 & $<0.0001$ \\
\hline Quercus myrsinaefolia & $\ln \mathrm{Y}=-2.7303+1.8411 \ln \mathrm{bh}$ & 0.9846 & $<0.0001$ \\
\hline${ }^{*} \mathrm{Y}$ : Carbon uptake $(\mathrm{kg} / \mathrm{tree} / \mathrm{yr})$
\end{tabular}

하지 않았다. 탄소흡수량 역시 줄기직경 만을 독립변수로 적용 하여 산출하는 것이 현장측정 변수의 간소화, 수고 관련 적용 오차 제어 등 활용의 용이성이나 실용성이 더 높을 수 있다.

상기한 계량모델을 적용하여 수종 및 직경별 탄소흡수량을 산정한 결과(Table 7 참조), 수목 1주당 탄소흡수량은 탄소저 장량과 유사하게 직경생장과 더불어 증가하였고, 직경급 간 흡 수량의 차이도 직경이 클수록 더욱 현저하였다. 즉, 직경이 $2 \mathrm{~cm}$ 커질 때마다 각 수종의 탄소흡수량은 최소 1.2 최대 3.0 배 증가하는 것으로 나타났다. 수종별로는 흉고직경 $10 \mathrm{~cm}$ 기 준 가시나무가 $4.5 \mathrm{~kg}$ 주년이고, 근원직경 $10 \mathrm{~cm}$ 의 동백나무와 배롱나무가 각각 $2.6 \mathrm{~kg}$ /주/년 및 $1.2 \mathrm{~kg}$ /주/년이었다. 중부지방 에 식재된 여러 조경수종의 탄소흡수량(Jo and Ahn, 2012; Jo et al., 2014)과 비교하면 본 가시나무의 경우는 동일 규격의 낙 엽수종 평균치인 약 $3.5 \mathrm{~kg}$ /주/년보다 1.3 배 그리고 상록수종 평균치인 $2.0 \mathrm{~kg}$ /주/년보다 2.3 배 더 많았다. 한편, 남부지방에 서 생장하는 낙엽성 참나무류 산림수목의 평균 탄소흡수량은 동일 규격 기준 $3.2 \mathrm{~kg}$ /주/년으로서(Jo and Ahn, 2000) 본 가 시나무는 이보다 1.4 배 많은 탄소흡수량을 나타냈다. 기존 연구 (Jo et al., 2014)에 따르면 근원직경 $10 \mathrm{~cm}$ 인 산수유와 주목의 탄소흡수량은 각각 $3.2 \mathrm{~kg}$ /주/년 및 $0.6 \mathrm{~kg} /$ 주/년이었다. 본 동 백나무와 배롱나무의 동일 규격 기준 탄소흡수량은 산수유보 다 적고, 주목보다는 훨씬 더 많았다. 흥고직경 $10 \mathrm{~cm}$ 인 가시나 무 한 그루는 약 $8 \mathrm{~L}$ 의 휘발유 소비, 그리고 근원직경 $10 \mathrm{~cm}$ 인 동백나무와 배롱나무는 2 5L의 휘발유 소비에 따라 배출되는 탄소량을 매년 상쇄하는 탄소흡수원 역할을 담당하였다.

Table 7. Carbon uptake per tree by diameter growth of study species (kg/tree/yr)

\begin{tabular}{c|c|c|c|c|c|c|c|c}
\hline \multirow{2}{*}{ Species } & \multicolumn{7}{|c}{ Diameter $(\mathrm{cm})$} \\
\cline { 2 - 10 } & 4 & 6 & 8 & 10 & 12 & 14 & 16 & 18 \\
\hline Camellia japonica & 0.2 & 0.6 & 1.4 & 2.6 & 4.4 & - & - & - \\
\hline Lagerstroemia indica & 0.3 & 0.6 & 0.9 & 1.2 & 1.6 & 2.0 & 2.5 & - \\
\hline Quercus myrsinaefolia & 0.8 & 1.8 & 3.0 & 4.5 & 6.3 & 8.4 & 10.7 & 13.3 \\
\hline
\end{tabular}

\section{IV. 결론}

최근 국제적 관심사인 저탄소 생활환경의 구현은 신재생에 너지 이용과 화석연료 절감, 녹지의 확충과 보전 등을 통해서 가능하다. 주민 생활공간의 조경식재를 통한 녹지확충은 탄소 저감에 공헌할 수 있는 중요한 조경분야의 사업이며, 국제적으 로 인정되는 탄소흡수원 증진활동이다. 이 사업에 필요한 우선 적 당면과제는 조경수목이 생장에 따라 얼마나 탄소를 흡수 및 저장하는지에 대한 신뢰성 있는 정보의 구축이나, 관련 국내 연구가 아직 미흡한 상황이다. 도시 조경수목의 탄소저감 관련 
기존 연구는 흔히 산림수목의 계량모델을 대용하여 산정한 것 으로서 잠재적 오류의 검증 및 보완을 요구한다. 특히, 난온대 기후권에서 생장하는 수종별 도시 조경수목의 탄소저장 및 흡 수를 계량화한 연구는 부재하는 실정이다.

따라서, 본 연구는 남부지방에 흔히 식재하는 3 개 조경수종 을 대상으로 직접수확법을 통해 단목의 탄소저장 및 흡수를 계 량화하고, 수종별 생장에 따른 탄소저감을 용이하게 산정하는 계량모델을 개발하여 해당 지방 도시의 식재수목에 의한 탄소 흡수원 역할을 구명하는데 유용할 기반정보를 구축하였다. 연 구대상 수종은 동백나무, 배롱나무 및 가시나무로서, 수종에 따 라 유목에서 성목에 이르는 일정 간격의 줄기직경 규격을 고려 하여 정상적으로 개방 생장하는 총 30 개체의 수목을 구입하고, 현장에서 근굴취를 포함한 직접수확법을 통해 개체당 부위별 생중량을 측정하였다. 개체별로 줄기, 가지, 잎, 뿌리 등으로 구 분한 표본을 채취하여 건조시킨 뒤, 해당 개체의 부위별 및 전 체 생체량을 파악하여 탄소저장량을 산정하였다. 수종별 흥고 직경 내지 근원직경의 줄기 원판을 채취하여 연간 직경생장을 분석하고, 탄소흡수량을 산출하였다. 줄기직경을 독립변수로 생 장에 기인한 수종별 단목의 탄소저장 및 흡수를 산출하는 활용 용이한 계량모델을 도출하였다. 아울러, 연구대상 수종의 생체 량 확장계수, 지하부/지상부 비율, 직경 생장률 등 생장특성 관 련 부재하는 실측 정보도 마련하였다.

본 연구에서 유도한 탄소저장 및 흡수를 산정하는 6 개 계량 모델의 $r^{2}$ 은 0.94 0.98 범위로서 적합도가 양호하였고, Y 절편 및 직경의 회귀계수도 $1 \%$ 수준에서 유의성을 나타냈다. 단목 의 탄소저장량과 흡수량은 직경생장과 더불어 증가하였고, 직 경급 간 그 차이도 직경이 클수록 더욱 현저하였다. 흥고직경 $10 \mathrm{~cm}$ 인 가시나무 단목의 탄소저장량과 흡수량은 각각 $24.0 \mathrm{~kg} /$ 주 및 $4.5 \mathrm{~kg} /$ 주/년이었다. 근원직경 $10 \mathrm{~cm}$ 인 동백나무와 배롱 나무의 경우는 각각 $11.2 \mathrm{~kg} /$ 주 및 $2.6 \mathrm{~kg} /$ 주 $/$ 년, $8.1 \mathrm{~kg} /$ 주 및 $1.2 \mathrm{~kg}$ /주/년이었다. 이 탄소저장량은 가시나무 약 $42 \mathrm{~L}$, 동백나 무 $20 \mathrm{~L}$, 배롱나무 $14 \mathrm{~L}$ 의 휘발유 소비에 따라 배출되는 탄소량 에 상당하였다. 또한, 상기한 직경의 가시나무, 동백나무 및 배 롱나무 한 그루는 해마다 각각 $8 \mathrm{~L}, 5 \mathrm{~L}, 2 \mathrm{~L}$ 의 휘발유 소비에 따른 탄소배출량을 상쇄하는 역할을 담당하였다. 본 결과는 연구 수종의 탄소저장 및 흡수와 관련 기존 연구가 전무하여 직접적으로 비교 분석할 수 없었으나, 타 조경수목이나 산림수 목의 경우와 비교 분석하여 탄소저감 관련 조경식재에 필요한 기반정보를 제공하였다. 연구대상 수목의 생체량 확장계수는 수령 차이, 개방 생장에 따른 지엽밀도 차이, 관리에 따른 생 장환경 개선 등에 기인하여 상록성 산림수목보다 큰 것으로 나 타났다.

본 연구는 정부 또는 기업의 도시녹지 사업과 관련하여 남부 지방 도시에 식재된 대상 조경수종의 탄소저감을 계량화할 수
있는 초석을 마련하였다. 연구과정에서 나타난 대표적 난제는 식재수목의 벌목을 위한 다수 표본의 확보와 고가의 구입비, 표본수목의 근굴취를 포함한 직접 벌목과 부위별 생중량 측정, 다수 생중량 표본의 장기간 건조과정과 계량분석 등이었다. 특 히, 벌목 대상의 대형 수목을 확보하기가 불가하였고, 소형 수 목임에도 요구하는 고가의 구입비는 표본수 확충의 제한요소 이었다. 본 연구대상 수목은 유목 내지는 성장과정의 표본들로 서, 탄소저장 및 흡수를 포함한 연구결과의 적용은 대상수목의 직경범위에 국한함이 바람직하다. 향후, 남부지방의 다양한 수 종과 대형 수목을 포함하는 추가 연구를 수행하여, 본 결과의 고찰과 더불어 저탄소 생활환경 창출에 기여하는 조경식재의 중요성을 강조할 필요가 있다.

\section{References}

1. Chow, P. and G. L. Rolfe(1989) Carbon and hydrogen contents of short rotation biomass of five hardwood species. Wood and Fiber Science 21(1) : 30-36.

2. Dirr, M. A.(2009) Manual of Woody Landscape Plants. Champaign, IL: Stipes Publishing Company.

3. DMC(Daegu Metropolitan City) (2017) Urban Parks in Daegu.

4. Jo, H. K. and D. H. Cho(1998) Annual $\mathrm{CO}_{2}$ uptake by urban popular landscape tree species. Journal of the Korean Institute of Landscape Architecture 26(2): 38-53.

5. Jo, H. K. and E. G. McPherson(1995) Carbon storage and flux in urban residential greenspace. Journal of Environmental Management 45: 109-133.

6. Jo, H. K. and H. M. Park (2017) Changes in growth rate and carbon sequestration by age of landscape trees. Journal of the Korean Institute of Landscape Architecture 45(5): 97-104.

7. Jo, H. K. and T. W. Ahn(2000) Indicators of carbon storage and uptake by tree growth in natural ecosystem. Korean Journal of Environment and Ecology 14(3): 175-182.

8. Jo, H. K. and T. W. Ahn(2001) Annual $\mathrm{CO}_{2}$ uptake and atmospheric purification by urban coniferous trees: For Pinus densiffora and Pinus koraiensis. Korean Journal of Environment and Ecology 15(2): 118-124.

9. Jo, H. K. and T. W. Ahn(2012) Carbon storage and uptake by deciduous tree species for urban landscape. Journal of the Korean Institute of Landscape Architecture 40(5): 160-168.

10. Jo, H. K. (2002) Impacts of urban greenspace on offsetting carbon emissions for middle Korea. Journal of Environmental Management 64: 115-126.

11. Jo, H. K., J. Y. Kim and H. M. Park(2013) Carbon storage and uptake by evergreen trees for urban landscape: For Pinus densiflora and Pinus koraiensis. Korean Journal of Environment and Ecology 27(5): 571-578.

12. Jo, H. K., J. Y. Kim and H. M. Park(2014) Carbon reduction effects of urban landscape trees and development of quantitative models: For five native species. Journal of the Korean Institute of Landscape Architecture 42(5): 13-21.

13. Jo, H. K., Y. H. Yun and K. E. Lee(1995) Atmospheric $\mathrm{CO}_{2}$ sequestration by urban greenspace - In the case of Chuncheon. Journal of the Korean Institute of Landscape Architecture 23(3): 80-93.

14. KFRI(Korea Forest Research Institute) (2007) Survey Manual for Forest Biomass and Soil Carbon. Seoul. 
15. KFRI(Korea Forest Research Institute) (2010a) Greenhouse Gas Inventory of Urban Green Areas: In Case of Seoul Metropolis. Research Report 10-19.

16. KFRI(Korea Forest Research Institute) (2010b) Carbon Emission Coefficients of Major Tree Species to Inventory Greenhouse Gases from Forests. Research Report 10-25.

17. KFRI (Korea Forest Research Institute) (2012) A Role of Urban Forests as a Carbon Uptake Source. Research Report 20

18. KFRI(Korea Forest Research Institute) (2014) Carbon Emission Factors and Biomass Allometric Equations by Species in Korea. Research Report 44-70

19. KFS(Korea Forest Service) (2014) Street Trees in Korea. Daejeon.

20. KIAST(Korean Institute of Agricultural Science and Technology) (2000) Methods of Analysis for Soil and Plants. Suwon.

21. KILA(Korean Institute of Landscape Architecture) (2016) Landscape Design Standards. Seoul.

22. McGovern, M. and J. Pasher (2016) Canadian urban tree canopy cover and carbon sequestration status and change 1990-2012. Urban Forestry \& Urban Greening 20: 227-232.

23. McPherson, E. G.(1998) Atmospheric carbon dioxide reduction by Sacramento's urban forest. Journal of Arboriculture 24(4): 215-223.

24. Nowak, D. J. and D. E. Crane(2002) Carbon storage and sequestration by urban trees in the USA. Environmental Pollution 116: 381-389.

25. Nowak, D. J.(1994) Atmospheric carbon dioxide reduction by Chicago's urban forest. In E. G. McPherson, D. J. Nowak and R. A. Rowntree, eds., Chicago's Urban Forest Ecosystem: Results of the Chicago Urban Forest Climate Project. General Technical Report NE-186. Radnor, PA: USDA Forest Service, Northeastern Forest Experiment
Station. pp. 83-94.

26. Nowak, D. J., E. J. Greenfield, R. E. Hoehn and E. Lapoint(2013) Carbon storage and sequestration by trees in urban and community areas of the United States. Environmental Pollution 178: 229-236.

27. Park, E. J. and K. Y. Kang(2010) Estimation of C storage and annual $\mathrm{CO}_{2}$ uptake by street trees in Gyeonggi-do. Korean Journal of Environment and Ecology 24(5): 591-600.

28. Park, I. H. and S. M. Lee(1990) Biomass and net production of Pinus densiflora natural forests of four local forms in Korea. Journal of Korean Forestry Society 79(2): 196-204.

29. Pingrey, D. W.(1976) Forest products energy overview. In Energy and the Wood Products Industry. Madison, WI: Forest Products Research Society. pp. 1-14

30. Rowntree, R. A. and D. J. Nowak(1991) Quantifying the role of urban forests in removing atmospheric carbon dioxide. Journal of Arboriculture 17(10): 269-275.

31. Song, C. Y., K. S. Chang, K. S. Park and S. W. Lee(1997) Analysis of carbon fixation in natural forests of Quercus mongolica and Quercus variabilis. Journal of Korean Forestry Society 86(1): 35-45.

32. UNFCCC(United Nations Framework Convention on Climate Change) (2006) Report of the Conference of the Parties Serving as the Meeting of the Parties to the Kyoto Protocol. Montreal.

33. Whittaker, R. H. and P. L. Marks(1975) Methods of assessing terrestrial productivity. In $\mathrm{H}$. Lieth and $\mathrm{R}$. $\mathrm{H}$. Whittaker, eds., Primary Productivity of the Biosphere. New York: Springer-Verlag. pp. $55-118$.

34. https://www.gir.go.kr

35. $h$ ttp://www.itreetools.org

36. http://www.law.go.kr
Received : 26 February, 2019

Revised : 22 April, 2019

24 May, 2019

(1st)

(2nd)

Accepted : 24 May, 2019 3 인익명 심사필 